\title{
State Postsecondary Education
}

\section{Commissions}

Reprinted from Higher Education and $\mathrm{Na}-$ tional Affairs 23, no. 10 (March 8, 1974).

The U.S. Office of Education this week [March 4-8, 1974] lifted a year's suspension of activity regarding state " 1202 " commissions and invited governors of each state and territory to establish commissions if they wish, leaving interpretation of requirements to them. The planning commissions, authorized under Section 1202 of the Higher Education Act, were viewed in March 1973 by the Administration as unnecessary and all activity toward their implementation was suspended (see Vol. XXII, Nos. 10 and 15).

This week's action, USOE said in a statement, "reflected a policy decision to place the responsibility for interpreting the "broadly and equitably representative' requirement for the Section 1202 state commissions in the hands of the states, instead of relying upon Federal regulations to guide state conduct in establishing the commissions."

In letters to the governors, U.S. Education Commissioner John Ottina said that a minimum of $\$ 1$ million is being reserved from appropriations for Fiscal Year 1974 to provide grants to the commissions. On this point, he said in his letter: "In accordance with Congressional intent, and after a careful review of the work which the Higher Education Facilities Commissions must complete during the remainder of Fiscal Year 1974, we have moved to limit the aggregate total of state allotments for work performed by the facilities commissions to a maximum figure of $\$ 2$ million, leaving at least $\$ 1$ million of the Section 1203 appropriation for Fiscal Year 1974 available to fund applications from Section 1202 State Commissions for Section 1203 planning grants and/or technical assistance."

The letters, asking for replies by April 15, indicated that the planning activities would be "comprehensive inventories of, and studies with respect to all public and private postsecondary educational resources in the state, including planning necessary for such resources to be better coordinated, improved, expanded or altered so that all persons within the state who desire, and who can benefit from postsecondary education may have an opportunity to do so." Ottina indicated that Section 1203 planning grant monies obligated during the current fiscal year would remain available for expenditure by the state commissions to support planning activities through the end of Fiscal Year 1975.

The law prescribes that the commissions must be "broadly and equitably representative of the general public and public and private nonprofit and proprietary institutions of postsecondary education in the state, including community colleges, junior colleges, postsecondary vocational schools, area vocational schools, technical institutes, four-year institutions of higher education and branches thereof."

Ottina told the governors that they can exercise three options in meeting criteria for the commissions: (1) establish an entirely new commission; (2) designate an existing agency or commission, if it meets the criteria; or (3) augment an existing commission or agency in order to meet the criteria.

Governors deciding to establish the commissions were asked by Ottina to furnish the following information:

(1) Which of the three options for establishing a Section 1202 Commission has your state chosen to follow: (a) creation of a new Commission, (b) designation of an existing state agency or state commission, or (c) expanding, augmenting or reconstituting the membership of an existing state agency or state commission?

(2) Which, if any, of the following stateadministered program authorities contained in the Higher Education Act has your state chosen to assign to the Section 1202 Commission: (a) Community Services and Continuing Education (HEA Section 105)? (b) Equipment for Undergraduate Instruction (HEA Section 603)? (c) Grants for Construction of Undergraduate Academic Facilities (HEA Section 704)?

(3) What is the Commission's official name, address and telephone number?

(4) What are the names, mailing addresses and terms of office of the Commission's members?

(5) What is the name, title, mailing address, and telephone number of the Commission's principal staff officer?

(6) A letter signed by you explaining how the membership of your State Commission meets the "broadly and equitably representative" requirements of Section 1202 (a) at the present moment, and what provisions have been made to insure continuing compliance with these requirements of the law. 